\title{
GEOMETRY AND DYNAMICS OF A SURGE-TYPE GLAGIER
}

\author{
By R. BindschadleR, \\ (Geophysics Program, University of Washington, Seattle, Washington 98195, U.S.A.) \\ W. D. Harrison, \\ (Geophysical Institute, University of Alaska, Fairbanks, Alaska 997or, U.S.A.) \\ C. F. RAymond and R. Crosson \\ (Geophysics Program, University of Washington, Seattle, Washington 98195, U.S.A.)
}

\begin{abstract}
Measurements of geometry, motion, and mass balance from Variegated Glacier, Alaska portray conditions in this surge-type glacier close to the mid-point of its 20 year surge cycle. Comparison of longitudinal profiles of ice depth, surface slope, and surface speed indicate that the motion occurs largely by internal deformation assuming the ice deforms according to the experimental law of Glen. Surface speed is not noticeably affected by local surface slope on the scale of the ice thickness or smaller, but correlates well with slope determined on a longitudinal averaging scale about one order of magnitude larger than the ice depth. The rate of motion on Variegated Glacier agrees well with rates on non-surge type temperate glaciers which have similar depth and slope. Although the flow regime at the time of the measurements is apparently typical of temperate glaciers, a large discrepancy between the balance flux needed for steady state and the actual flux is indicative of a rapidly changing surface elevation profile and internal stress distribution.
\end{abstract}

Résumé. Géométrie et dynamique d'un glacier a crues rapides. Des mesures de la géométrie, du mouvement et du bilan du Variegated Glacier en Alaska cernent les conditions dans lesquelles se trouve ce glacier à crues rapides exactement à mi-parcours des vingt années de son cycle de crues. La comparaison des profils longitudinaux de la profondeur de la glace, de la pente de la surface, et de la vitesse à la surface indiquent que le mouvement se produit surtout par déformation interne, la déformation semblant se faire en conformité avec la loi expérimentale de Glen. La vitesse superficielle n'est pas notablement affectée par la pente superficielle locale à l'échelle de l'épaisseur de la glace ou à une échelle plus petite, mais elle est en bon accord avec la pente déterminée sur une échelle longitudinale moyenne d'environ un ordre de grandeur plus grande que l'épaisseur de la glace. La vitesse du mouvement du Variegated Glacier est en bon accord avec la vitesse des glaciers tempérés non sujets à crues rapides qui ont des épaisseurs et des pentes comparables. Bien que le régime de l'écoulement au moment des mesures est apparemment typique des glaciers tempérés, une grande discordance entre le bilan qui serait nécessaire pour créer un état d'équilibre et le bilan réel indiquent de rapides changements dans l'altitude de la surface et dans la distribution des efforts internes.

Zusammenfassung. Geometrie und Dynamik eines Ausbruchsgletschers. Messungen der Geometrie, der Bewegung und der Massenbilanz am Variegated Glacier, Alaska, erweisen die Verhältnisse in diesem Ausbruchsgletscher als sehr ähnlich denen in der Mitte seines 20-jährigen Ausbruchszyklus. Der Vergleich von Dickenprofilen in der Längsachse, von Oberflächenneigungen und -geschwindigkeiten deutet darauf hin, dass die Bewegung unter der Annahme einer Deformation nach dem experimentellen Glen'schen Gesetz weitgehend durch innere Deformation zustande kommt. Die Oberflächengeschwindigkeit wird im Ausmass der Eisdicke oder kleiner nicht merklich durch die lokale Oberflächenneigung beeinflusst, doch ist sie eng mit der Neigung korreliert, die aus einem mittleren Längsausmass, etwa eine Grössenordnung grösser als die Eisdicke, hergeleitet wird. Die Geschwindigkeit des Variegated Glacier stimmt gut mit jener von nicht-ausbrechenden temperierten Gletschern von ähnlicher Dicke und Neigung überein. Obwohl die Fliessverhältnisse zur Zeit der Messungen offensichtlich typisch die eines temperierten Gletschers waren, deutet eine starke Diskrepanz zwischen dem Gleichgewichtsfluss, der für einen stationären Zustand benötigt wird, und dem tatsächlichen Fluss auf schnelle Änderungen des Oberflächenprofiles und der inneren Spannungsverteilung hin.

\section{Introduction}

Much valuable descriptive information about surge behavior (Meier and Post, I969; Post, I969; Stanley, r969) and some geophysical data from a few surge-type glaciers (Dolgushin and Osipova, [1975]; Classen and Clarke, I97 I C Collins, I972; Jarvis and Clarke, I974, I975; Clarke and Goodman, I975; Goodman and others, 1975) have been gathered. However, the scope of these data are not sufficient to distinguish with certainty between various possible physical explanations of surge behavior. In order to help fill this gap we 
have made measurements of surface and bed geometry, surface motion, near-surface temperature and mass balance on the surge-type Variegated Glacier, Alaska. An earlier paper established that the Variegated Glacier is temperate and that its surges cannot be explained by thermal triggering (Bindschadler and others, I976). Detailed compilations of data are presented in three reports available through World Data Center A-Glaciology (Bindschadler and others, unpublished) which will hereafter be referred to as DR 73 , DR 74, and DR 75 . The purpose of this paper is to summarize these measurements in order to define the spatial distribution of geophysical parameters and the dynamic condition of the glacier half-way through an interval between surges. The relationship between flow speed, ice depth, and surface slope is comparable to that found for normal non-surge-type temperate glaciers. In testing the data against some of the basic concepts of glacier mechanics, it is found that the surface velocity distribution is strongly influenced by longitudinal stress gradients.

\section{Description of Variegated Glacier and its surges}

Variegated Glacier lies approximately $55 \mathrm{~km}$ north-north-east of Yakutat, Alaska, near the junction of Russell Fjord and Disenchantment Bay in the coastal St. Elias Mountains. It runs about $20 \mathrm{~km}$ from east to west along latitude $60^{\circ} \mathrm{N}$. with a relatively uniform slope of about $5 \mathrm{deg}$ from its head at about $\mathrm{I} 950 \mathrm{~m}$ elevation to its terminal area near tide-water. Surface width is about I $\mathrm{km}$ except for the two accumulation basins and the terminal lobe, where it is wider (Fig. I). Because of its relatively low elevation in a maritime environment, one expects that the glacier would be temperate; this has been verified by direct observations reported elsewhere (Bindschadler and others, 1976 ).

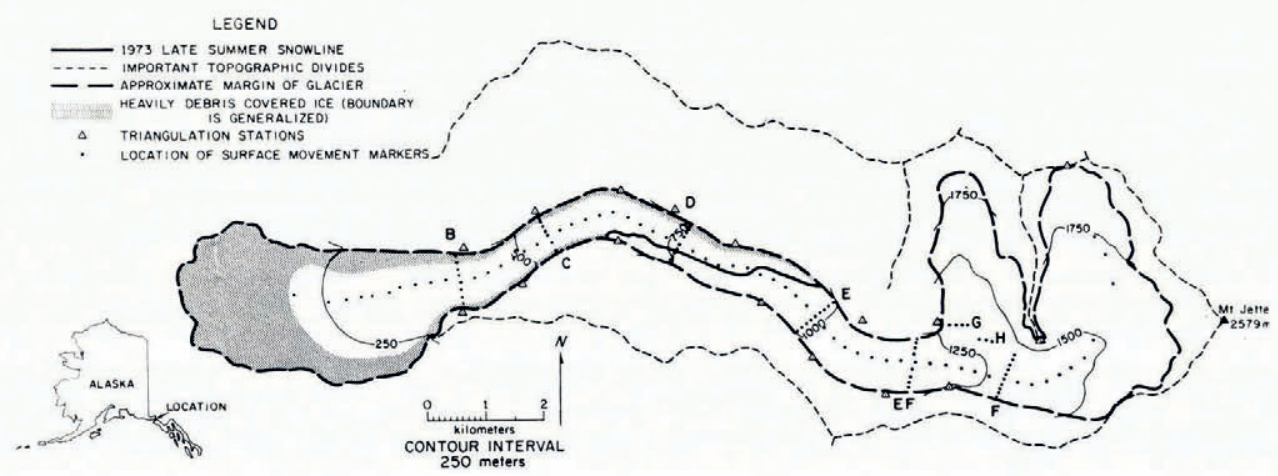

Fig. I. Map of Variegated Glacier showing measurement sites.

The glacier has a history of spectacular surges documented by direct observation and photography going back to 1895 (Tarr and Martin, I9I4; also unpublished International Boundary Commission photographs in I9II; unpublished photographs by B. Washburn from 1933; United States Air Force photographs in 1942; United States Navy photographs in 1948; and Austin Post's unpublished photographs from I964 and 1965). These sources indicate that surges occurred during r905 to I906, sometime between I9I I and I933, between 1942 and 1948 , and during 1964 to 1965 . Although a precise periodicity is not proven by this history, a regular surge period of about 20 years is suggested, as was first proposed by Post ( 1969 ) on the basis of slightly less complete photographic data. The results presented in this paper from observations in 1973 and 1974 therefore portray conditions close to the midpoint of the 20 year surge cycle. 
The past surges of Variegated Glacier were quite spectacular and fit the description of Type I defined by Meier and Post (1969). The aerial photography from I 948 and 1965 shows that almost the whole glacier participated in the fast motion of the last two surges; only a few small areas in the high accumulation area and near the terminus did not participate. During the $1964-65$ surge, ice starting out in the vicinity of section B (Fig. I) was displaced about $3 \mathrm{~km}$ horizontally. The quantitative change in the surface elevation profile caused by the last surge is not known; however, Post's photographs suggest that the boundary between the ice reservoir and ice receiving areas lay somewhere between sections B and C.

\section{Geometry of the glacier}

Triangulation stations were established on the valley sides for the purpose of surveying points on the ice surface. Approximate locations of these stations are shown in Figure $\mathbf{I}$. Coordinates in a local coordinate system were determined by theodolite triangulation and distance ranging. A detailed description of the geodetic control and station coordinates is given in DR 73, DR 74, and DR 75. In this paper elevations are expressed relative to a vertical datum of approximate mean sea-level.

Survey of markers on the ice surface shown in Figure I gives the longitudinal profile of surface elevation shown in Figure 2 and transverse profiles of surface elevation across seven cross-profiles shown in Figure 3 .

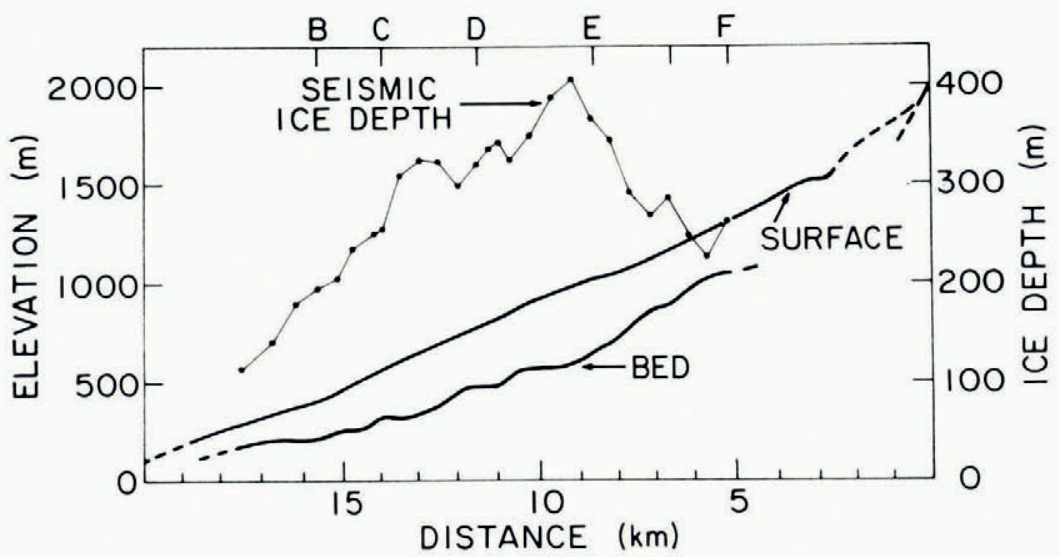

Fig. 2. Seismic ice depth measured from surface at center-line, and longitudinal profiles of surface elevation (June I973) and nominal bed elevation at center-line. Bed elevation is deduced assuming the measured distance from surface to bed is in a vertical longitudinal plane. Horizontal distance is measured along center-line from head of glacier.

Ice depths were measured by seismic reflection methods. The recording unit was a I 2 channel oscillograph (SIE Model RS-4) with channel outputs plotted on self-developing lightsensitive paper (Kodak linagraph direct print type 1895). Simple electronic modification increased the relative sensitivity at higher frequencies $\left(5^{-125} \mathrm{~Hz}\right)$, and a fast paper drive speed of $0.6 \mathrm{~m} \mathrm{~s}^{-1}$ was used. Twelve sensors equally spaced over a distance of $\mathrm{i} 6 \mathrm{o} \mathrm{m}$ were set out for each reflection shot. Each sensor consisted of two geophones (free period $30 \mathrm{~Hz}$ ) electrically connected in parallel and set vertically just beneath the surface about $\mathrm{I} \mathrm{m}$ apart. The acoustic source was generated by detonation of a small amount of high-speed explosive (o.o I to $0 . \mathrm{I} l$ of Astrolite-T, detonation velocity of $8000 \mathrm{~m} \mathrm{~s}^{-1}$ ) at depths of $\mathrm{I}$ to $\mathrm{I} 7 \mathrm{~m}$ below the surface. Reflection signals were typically roo to $175 \mathrm{~Hz}$ and arrival times could be identified with better than I ms accuracy. 
For analysis of the travel times, the ice was assumed isotropic and homogeneous. This is reasonable everywhere except for areas of deep firn, where a low firn velocity could result in the depths being overestimated. The ice velocity used in the data reduction was $3610 \mathrm{~m} \mathrm{~s}^{-1}$, measured by Paterson and Savage (1963) on the Athabasca Glacier. With this velocity, the contribution to the error in depth determination from errors in timing reflected arrivals amounts to $\pm 1.3 \mathrm{~m}$. Rough estimates of acoustic velocity from timing of first arrivals across various geophone spreads were generally compatible with the value of Paterson and Savage,
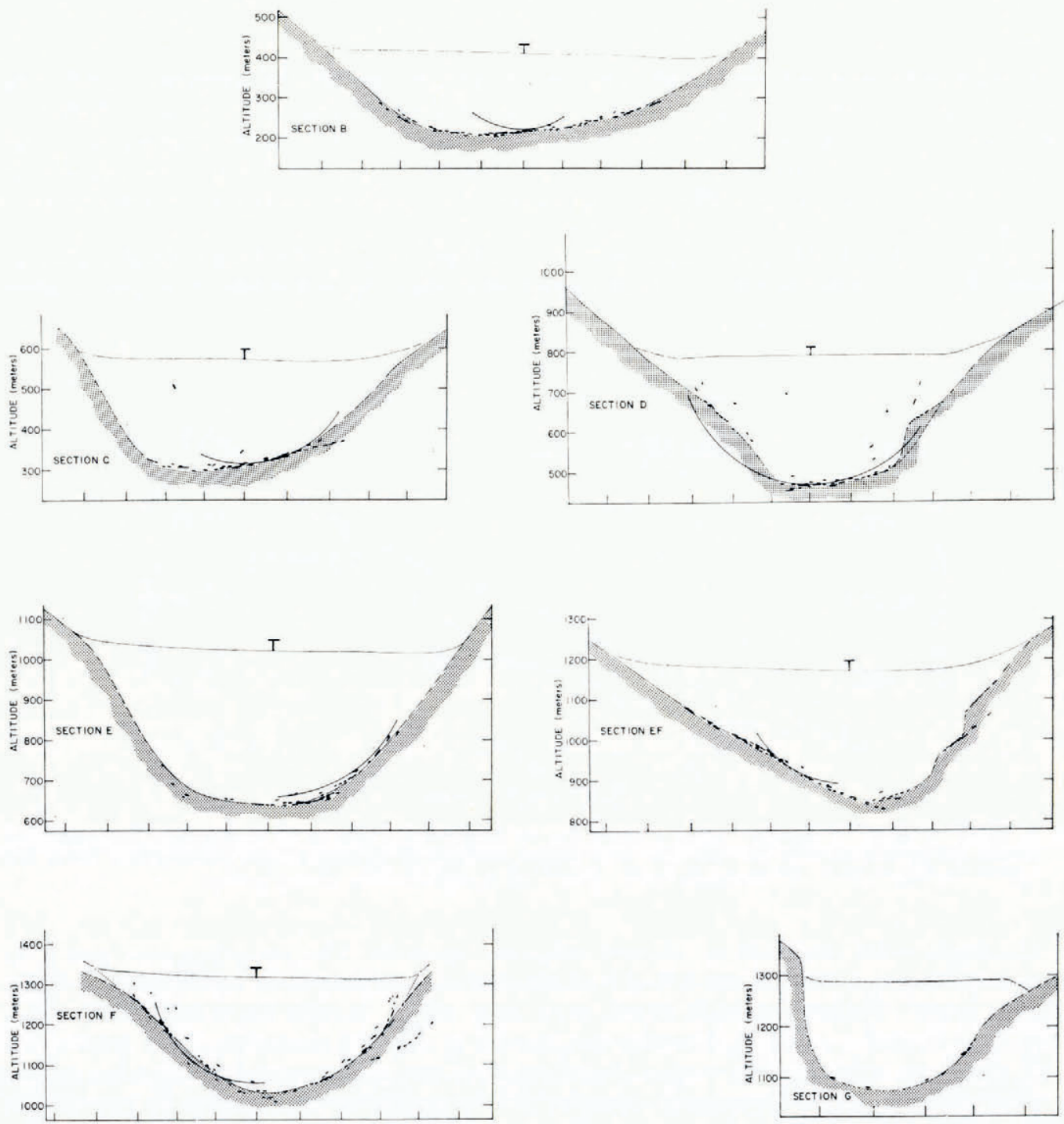

Fig. 3. Geometry of cross-sections from surface and seismic survey. Hatches are the reflections calculated from travel times to adjacent geophones in transverse spreads. Arc indicates distance to bed determined from longitudinal spread centered on location indicated by $T$. Dashed lines show inferred bed where reflections are absent. Valley walls were measured from 1948 and I96r maps compiled by the United States Geological Survey. Dotted lines in section F show assumed limits of section for determination of quantities in Table I. Horizontal and vertical scales are equal in each diagram. (Note different scale for section $G$.) 
but showed some deviations ranging from $-4 \%$ to $+3 \%$ of their value and a tendency to be slightly higher. This introduces uncertainty about the proper acoustic velocity and an additional, possibly systematic error in depth measurement, but this is not likely to exceed $3 \%$.

Reflection measurements were made at about one-half kilometer spacing along the central longitudinal line of stakes with the results shown in Figure 2, and across the seven transverse lines with the results shown in Figure 3. More detailed data and larger-scale plots are available in DR 73 and DR 74 .

On the longitudinal line two shots were made at each location: one at the center of a longitudinal spread and the other at the center of a transverse spread. Standard reflection analysis (Dobrin, I96o, p. I08) of the travel times of the reflected waves across each spread gave the distance to the bed and the longitudinal and transverse slopes. In some cases, the transverse slope of the reflecting horizon was substantial (up to $37^{\circ}$ ), indicating a measurement along an inclined path to a point on the sloping valley wall (see sections $\mathrm{E}, \mathrm{EF}$, and $\mathrm{F}$ in Figure 3 for examples). However, in most cases the determined distance to the bed is probably a good approximation to the depth measured in a vertical longitudinal plane along the deepest part of the valley.

Measurements at each of the transverse sections (Fig. 3) included additional transverse spreads and shot locations. The locations of reflecting horizons were determined for every pair of adjacent geophones for which P-wave arrival times could be identified. Various geometrical parameters of the cross sections are listed in Table I.

Table I. Geometrical parameters of cross sections

\begin{tabular}{|c|c|c|c|c|}
\hline Section & $\begin{array}{c}\text { Center-line } \\
\text { depth } \\
H \\
\mathrm{~m}\end{array}$ & $\begin{array}{c}\text { Surface } \\
\text { width } \\
W \\
\mathrm{~km}\end{array}$ & $\begin{array}{c}\text { Length of } \\
\text { ice-rock contact } \\
P \\
\mathrm{~km}\end{array}$ & $\begin{array}{c}\text { Cross-section } \\
\text { area } \\
\begin{array}{c}A \times \mathrm{IO}^{-4} \\
\mathrm{~m}^{2}\end{array}\end{array}$ \\
\hline B & 206 & I.02 & 1.14 & 14.0 \\
\hline $\mathrm{C}$ & 278 & 0.86 & I. 12 & 15.4 \\
\hline D & 323 & 0.94 & 1.24 & 16.7 \\
\hline $\mathrm{E}$ & 384 & $0.9^{8}$ & 1. 35 & 24.1 \\
\hline EF & 326 & 1.03 & I. 32 & 18.2 \\
\hline F & 287 & 0.80 & I.04 & 14.2 \\
\hline G & 212 & 0.44 & 0.67 & 6.8 \\
\hline
\end{tabular}

\section{Motion of the glacier}

Surface markers were located by theodolite triangulation at several times in order to determine the pattern of surface velocity. On the lower part of the glacier (below section E, Fig. I) markers were soft-iron wires (approximately $3 \mathrm{~mm}$ diameter) steam-drilled into the ice to initial depths up to about ro $\mathrm{m}$, which was adequate to prevent melting out over one and most of a second ablation season. Flagged stakes were set up temporarily next to the wires at the time of sighting from bedrock stations. Most markers in the accumulation areas were stakes up to $5 \mathrm{~m}$ in length and were maintained only over the summer. At 12 locations, chrome-nickel alloy-steel tubing towers of segmented and tapered construction with lengths up to $12 \mathrm{~m}$ were erected for following the motion over the winter period. All of these survived the winter of $1973-74$, but similar towers did not survive the $1974-75$ winter.

The variation of center-line speed with longitudinal distance is shown in Figure 4 . The lateral variation of surface speed at the transverse sections is shown in Figure 5. The main measurement error is caused by imperfectly corrected displacements of markers relative to the ice due to tilting of wire holes, stakes, or towers. The error in speed depends on the measurement time period. For a time average over a full summer ( 2 months) or more, the error in speed does not exceed $0.02 \mathrm{~m} \mathrm{~d}^{-1}$ and at most locations is less than $0.01 \mathrm{~m} \mathrm{~d}^{-1}$. 


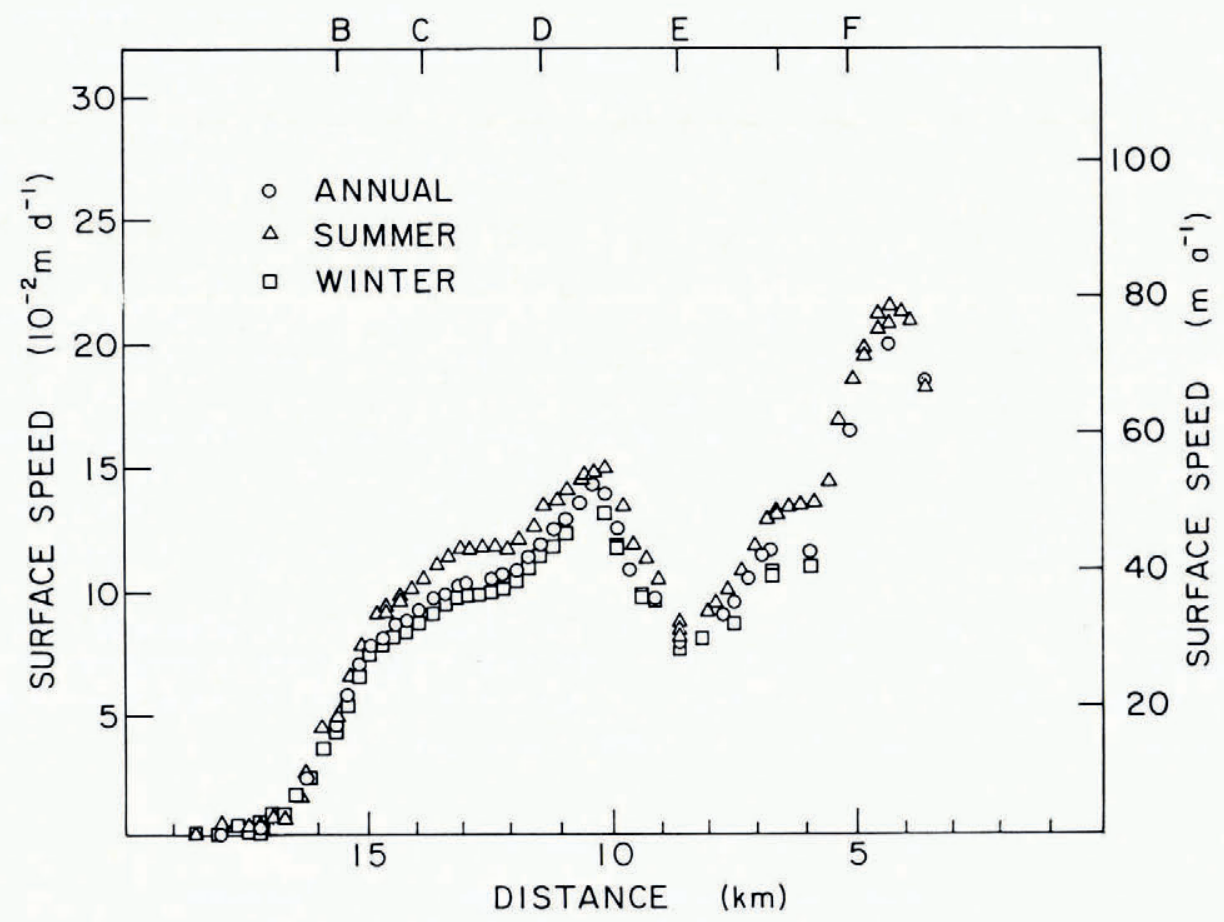

Fig. 4. Longitudinal variation of surface speed for time intervals: Summer (late June to early September 1973), Winter (September 1973 to Fune 1974), and Annual (September 1973 to September 1974).

\section{Present dynamics of the glacier}

\section{I. Surface speed and glacier geometry}

Standard theory (Nye, I952) gives a relationship between surface speed $u_{\mathrm{s}}$, surfacenormal ice depth $H$, surface slope $\alpha$, and a cross-section shape factor $f$ expressed by:

$$
u_{\mathrm{s}}=\frac{2 A}{n+\mathrm{I}}(f \rho g \sin \alpha)^{n} H^{n+\mathrm{I}}
$$

where $\rho$ is ice density, $g$ is gravitational acceleration, and $A$ and $n$ are the parameters in the power flow law $\dot{\epsilon}=A \tau^{n}$ determined experimentally by Glen (1955) and subsequent experiments. Equation ( $\mathrm{I}$ ) is derived assuming there are no longitudinal stress gradients and basal sliding is absent. The shape factor $f$ is introduced to take account of lateral stress gradients caused by drag at the valley sides and may depend on the depth. In a real situation where the slope of the upper surface is not constant, Equation (I) is not strictly applicable, but there are some theoretical arguments and observational evidence that it may still be approximately valid if the surface slope is computed on an appropriate length scale (Budd, I968; Meier and others, 1974).

Figure 6 shows the value of $f \sin \alpha$, denoted as $f_{\mathrm{v}} \sin \alpha_{\mathrm{v}}$, which is required for Equation (I) to predict correctly the measured annual speed (September 1973 to September I974) from the seismically determined depth. For this calculation $A$ was taken as $0.148 \mathrm{a}^{-1} \mathrm{bar}^{-4.2}$, $n=4.2$, and $\rho=0.9 \mathrm{Mg} \mathrm{m}^{-3}$ which corresponds to Glen's results for $-0.02{ }^{\circ} \mathrm{C}$. Also shown in Figure 6 is the actual surface slope averaged over several different length scales denoted as $\langle\sin \alpha\rangle$. 

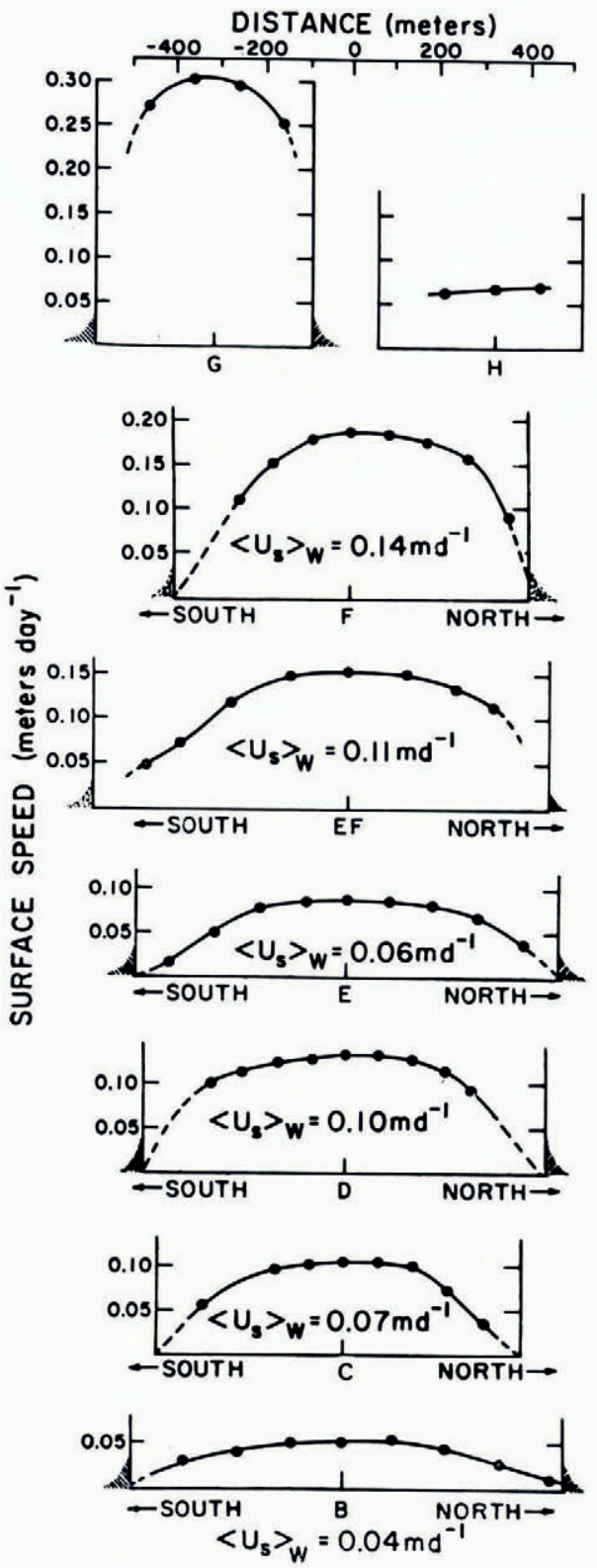

Fig. 5. Lateral variation of average surface speed over summer 1973 for sections $B, C, D, E, F, G, H$ and over summer 1974 for section EF. Speed averaged over the glacier width is given as $\left\langle u_{\mathrm{s}}\right\rangle_{\mathrm{w}}$. Hatches at a margin indicate the valley wall is exposed rock; stipples indicate it is firn or ice covered. 


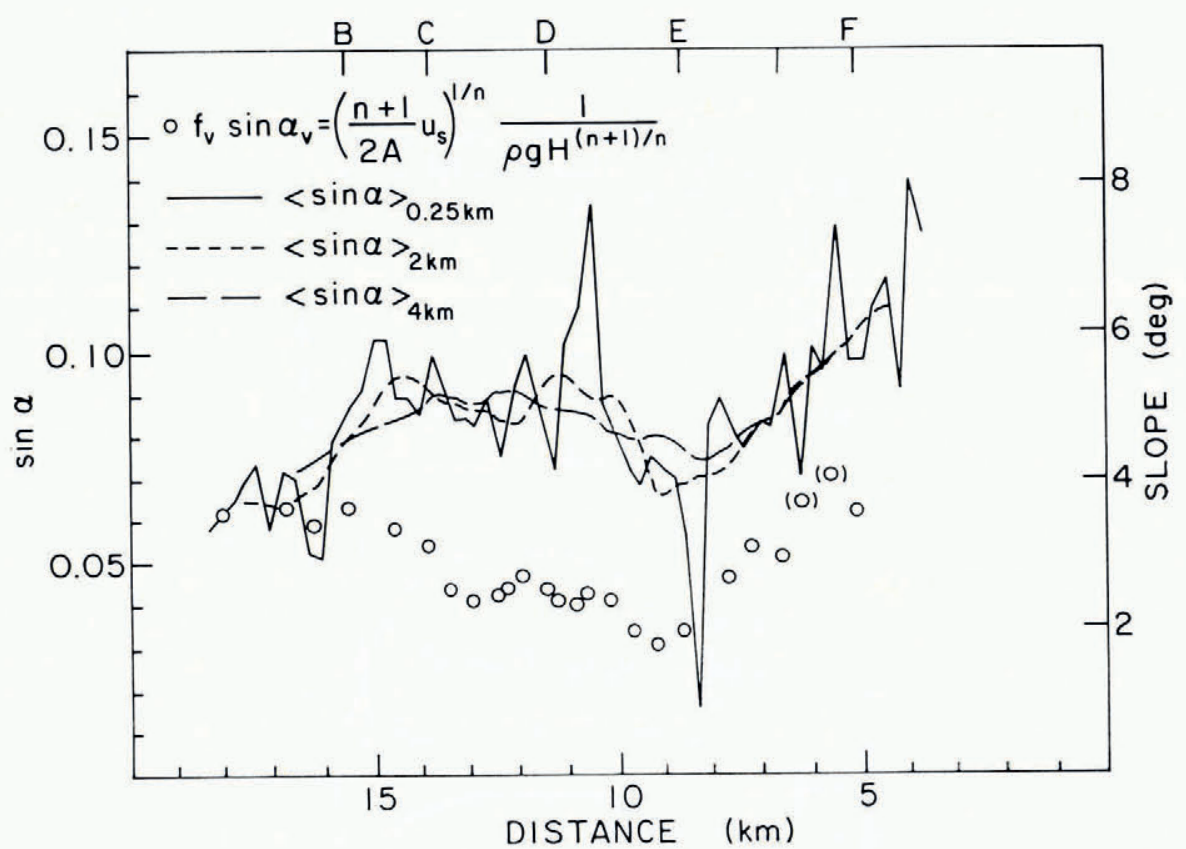

Fig. 6. Longitudinal profile of surface slope for various averaging scales compared to $f_{\mathrm{v}}$ sin $\alpha_{\mathrm{v}}$ predicted from measured ice depth and annual speed (summer speed for those points in parentheses). Average over $0.25 \mathrm{~km}$ was directly from surfacemarker elevations measured in Fune 1974. Two and four kilometer averages were computed from a continuous longitudinal profile estimated by interpolation between measured marker elevations.

Comparison of these slope averages shows that the measured slope averaged over $0.25 \mathrm{~km}$ (about one glacier depth) shows a much stronger variation with longitudinal distance than $f_{\mathbf{v}} \sin \alpha_{\mathbf{v}}$, which demonstrates clearly that the surface speed is not strongly influenced by fluctuations in surface slope of this scale. On the other hand, the surface slope averaged over 2 or $4 \mathrm{~km}$ has about the same smoothness as $f_{\mathrm{v}} \sin \alpha_{\mathrm{v}}$, which suggests that an averaging length of a number of glacier depths may be more appropriate for use in Equation (I). This is probably a consequence of longitudinal stress gradients (Budd, 1968), and is similar to the conclusion reached by Meier and others (1974) that internal deformation in Blue Glacier is controlled by a nearly constant effective slope equal to a large-scale average slope.

To test this further, the shape factor needs to be considered. Figure 7 shows the ratio of $f_{\mathrm{v}} \sin \alpha_{\mathrm{v}}$ to $\langle\sin \alpha\rangle$ averaged over $2 \mathrm{~km}$ and $4 \mathrm{~km}$. This gives the value of $f$ (denoted $f_{\mathrm{v}}$ ) needed to make the simple theory agree with the observations of surface speed and depth. This can be compared to values of $f$ determined from the actual glacier geometry (denoted $\left.f_{\mathbf{G}}\right)$. Values for $f_{\mathrm{G}}$ were estimated from the ratio of the half-width of the glacier to the centerline ice depth assuming a parabolic cross-section shape and no basal slip by using the numerical calculations of cross-section flow of Nye (1965). At each seismically determined cross-section, $f_{\mathrm{G}}$ was also determined by a numerical calculation similar to that of Nye but using the actual measured shape.

The discrepancies can probably be largely explained by errors in geometrical parameters such as locally shallow depth estimates caused by lateral deviation of the longitudinal line of measurement points on the glacier surface from the deepest part of the channel (likely at 6 and I $\mathrm{km}$ ), and deviation of the actual shape from the assumed parabolic shape for un- 


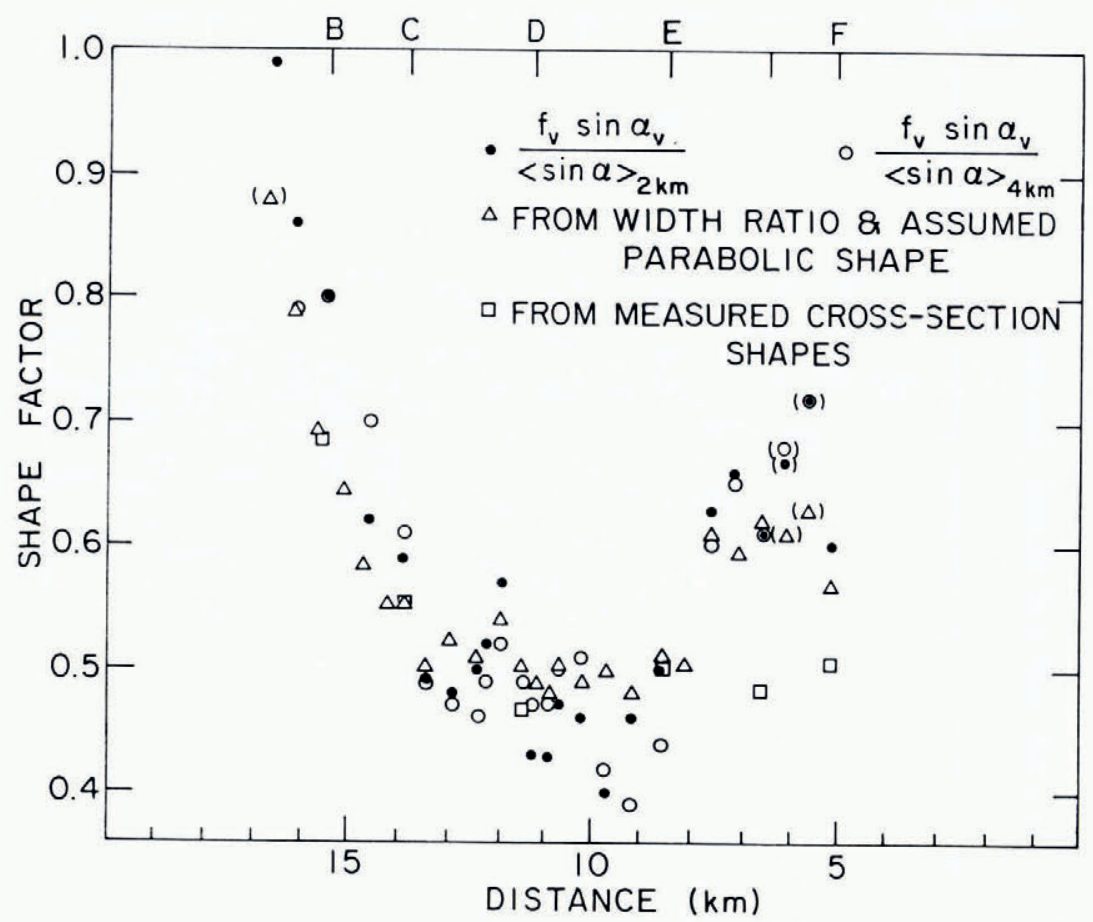

Fig. 7. Cross-section shape factors $f_{\mathrm{v}}$ deduced from measured surface velocity, surface slope, and ice depth compared to theoretical shape factors $f_{\mathrm{G}}$ deduced from cross-section shapes. Data points enclosed in parentheses represent cases where $f_{\mathrm{G}}$ is especially uncertain because of a poorly defined width or $f_{\mathbf{v}}$ is determined from averaged summer speed rather than annual speed.

measured cross-sections. The geometrical situation between kilometers 5 and 7 is especially complex as a consequence of the entrance of the one major tributary (Fig. I). If the Variegated Glacier ice were less viscous than predicted by the assumed quasi-viscous creep law of Glen (1955) or basal sliding contributes to the surface speed, then the estimates of $f_{\mathrm{v}}$ would be shifted upward with respect to their correct values. This might explain why estimates of $f_{\mathbf{v}}$ are slightly larger than for $f_{\mathrm{G}}$ over much of the measured length of the glacier, particularly in view of the fact that the variation of speed with time on a seasonal and shorter time scale has shown that there is some sliding motion during the summer (Bindschadler and others, I976). On the other hand there is a substantial zone between about 8 and ${ }_{1} 3 \mathrm{~km}$ over which estimates of $f_{\mathrm{v}}$ are smaller than for $f_{\mathrm{G}}$, which shows any systematic effect of flow law parameter errors or sliding is not of dominating influence. It also seems probable that some of the discrepancy is explained as a residual effect of longitudinal stress gradients which are only partially taken into account by the use of a large-scale surface slope (Budd, i968; Meier and others, 1974).

Even though there is some disagreement between $f_{\mathrm{v}}$ and $f_{\mathrm{G}}$ in Figure 7 , the agreement between the overall patterns of longitudinal variation is quite good. Comparisons between Figures 6 and 7 verify the applicability of the concept of a shape factor and establish with greater clarity than heretofore the need to use a surface slope averaged over a length a number of times the ice depth for computation of surface velocity from Equation (I). Based on Equation ( $\mathbf{I}$ ), the pattern of annually averaged motion on Variegated Glacier at the time of these measurements is apparently determined by internal deformation without significant contribution from sliding. 


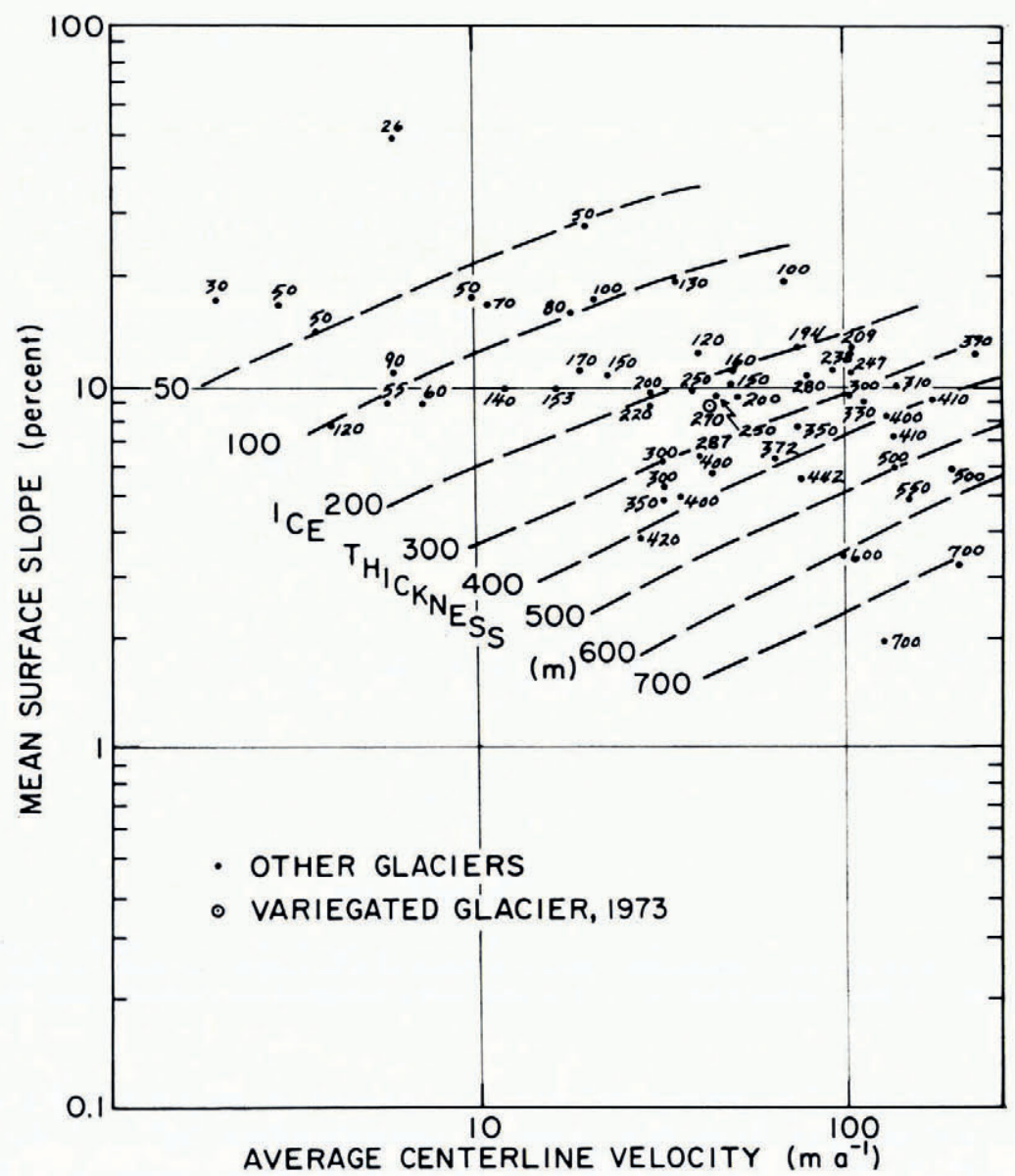

Fig. 8. Budd diagram. Plot of average center-line velocity versus mean surface slope for distinctive sections of a number of nonsurging glaciers compiled by Budd. Contours of mean ice thickness are included to emphasize the existing trend. Variegated Glacier $(\odot)$ in 1973 is seen to fit well with non-surge-type glaciers.

\subsection{Comparison with other glaciers}

Budd and Allison ([1975]) and Budd and Jenssen ([1975]) have given empirical relationships between the average surface slope, average center-line velocity, and average ice thickness of a glacier based on data from non-surge-type glaciers. Figure 8 is a diagram prepared by Budd, which shows the relationships and the data points on which they are based. The fairly regular pattern is consistent with Equation ( $I$ ), and it exists in part because shape factors for typical valley cross-sections fall in a narrow range. When Variegated Glacier is plotted on this diagram, it fits well into the pattern. This illustrates that the relationship between the present motion and geometry of Variegated Glacier is remarkably typical in comparison to normal glaciers.

\subsection{Base stress distribution}

Basal shear stress $\tau_{\mathrm{b}}$ is usually estimated from

$$
\tau_{\mathrm{b}}=\rho g f_{\mathrm{G}} \sin \alpha H
$$


where shape factor and slope are determined from the geometry. Based on Equation (I), $\tau_{\mathrm{b}}$ may be estimated alternatively from

$$
\tau_{\mathrm{b}}=\rho g f_{\mathrm{v}} \sin \alpha_{\mathrm{v}} H=\left[\frac{n+\mathrm{I}}{2 A} \frac{u_{\mathrm{s}}}{H}\right]^{1 / n} .
$$

From the analysis of Section 5.I and Figure 7, these two estimates are approximately equivalent as long as $\alpha$ is determined on a length scale of 2 to $4 \mathrm{~km}$. Results from Equations (2) and (3) are shown in Figure 9. The disagreement between the two estimates is a reflection of the disagreement between $f_{\mathrm{G}}$ and $f_{\mathrm{V}}$ in Figure 7 and arises from the same sources discussed in Section 5.I. Equation (3) is probably more reliable in this case. It has the advantages that it can be applied without knowledge of the cross-section shape and that it naturally tends to account for lateral and longitudinal stress gradients.

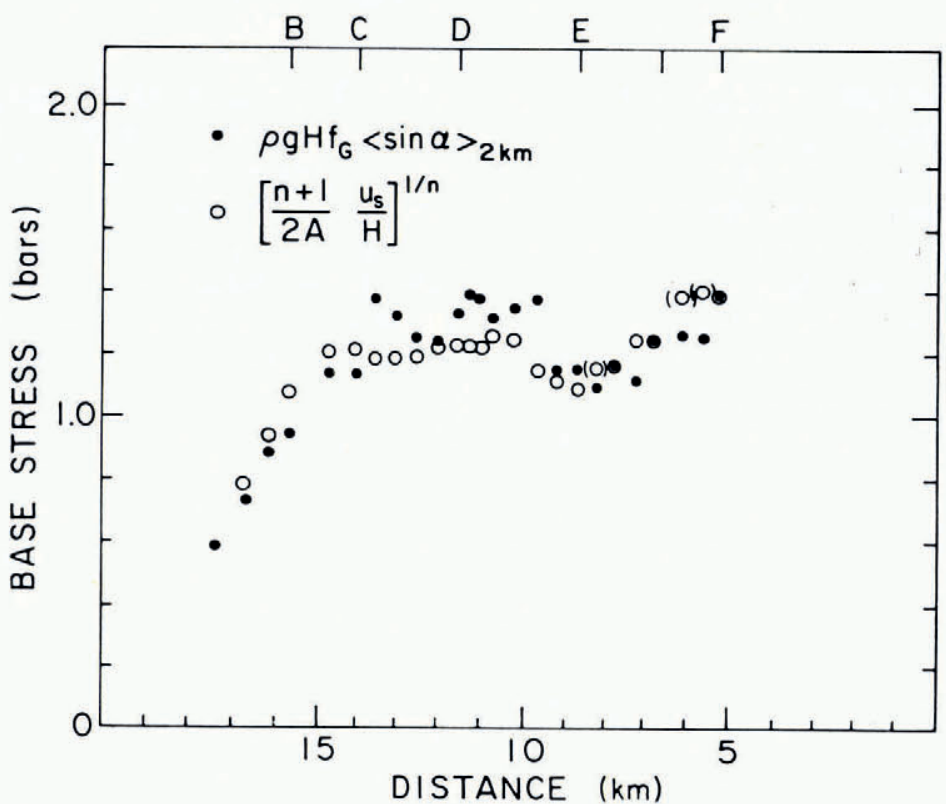

Fig. 9. Base stress distribution estimated from Equation (2) and Equation (3) using measured annual surface speed (summer speed for points in parentheses), surface slope and depths.

Over the central reach of the glacier $\tau_{\mathrm{b}}$ maintains a nearly uniform value of about 1.2 bar. However, there are two zones of negative basal shear-stress gradient: one in the terminal area below section B and the other below section F. According to Robin and Weertman (r973) such zones might be important in the initiation of a surge by blocking the flow of water along the base of the glacier. Aerial photography by Austin Post in 1964 soon after the onset of the last surge shows that fast motion was initiated well above section $\mathrm{B}$ and probably quite high on the glacier. These concepts and observations identify the zone below section $\mathrm{F}$ as a possibly critical area for the initiation of surges. However, according to the theory of Robin and Weertman (1973, p. I3, equation (13)), the size of the present base-stress gradient below section $\mathrm{F}$ of about $-\mathrm{O} . \mathrm{I} \times \mathrm{IO}^{-3} \mathrm{bar} \mathrm{m}^{-1}$ is inadequate to block the drainage of water with the present surface slope of 4 to $6 \mathrm{deg}$ and bed slope of -2 to $+17 \mathrm{deg}$ unless the bed roughness is substantially lower than the lowest values expected from Kamb's analysis of sliding (Kamb, I970, p. 706, table 2) or direct measurement on recently exposed glaciated bedrock (Hallet, г976). 


\subsection{State of balance}

Net balance for 1972-73 was measured at all markers in the ablation area, in a pit at section F, and with less certainty by probing at most markers in the accumulation area. Similar coverage was obtained for $1973-74$, but with improved data in the accumulation area from measurements on a line of 12 towers running from about $\mathrm{I} 500 \mathrm{~m}$ elevation $3.5 \mathrm{~km}$ from the head of the glacier down to $9 \mathrm{~km}$ near section E. Since there was no coverage in the high accumulation area of the main glacier or the tributary, only very rough estimates of total mass balance are possible. Figure ro shows estimates for balance flux distribution based on the $1972-73$ and $1973-74$ net balance distributions, details of which are reported in DR 73, DR 74, and DR 75. The balance flux $Q_{\mathrm{b}}$ is defined as

$$
Q_{\mathbf{b}}(x)=\iint_{A(x)} a \mathrm{~d} S
$$

where $a$ is the net balance in ice thickness equivalent and $A(x)$ is the area of the glacier surface above the longitudinal position $x$. The accuracy of the curves is hard to determine, but calculation with a range of reasonable extrapolations to the unmeasured high areas suggests that errors in balance flux do not exceed $10 \times 10^{6} \mathrm{~m}^{3} \mathrm{a}^{-1}$. Accumulation in the upper accumulation areas was conservatively estimated, so it is more likely that these curves are underestimates rather than overestimates. The long-term balance flux is probably more closely represented by the $1972-73$ curve since this was a fairly typical year in Yakutat, whereas 1973-74 was a dry year with an unusually clear dry summer. The balance flux determined at the equilibrium line for $1972-73$ of about $50 \times 10^{6} \mathrm{~m}^{3} \mathrm{a}^{-1}$ supports the estimate of $65 \times 10^{6} \mathrm{~m}^{3} \mathrm{a}^{-1}$ for this glacier made by Budd (1975, p. I I, table II).

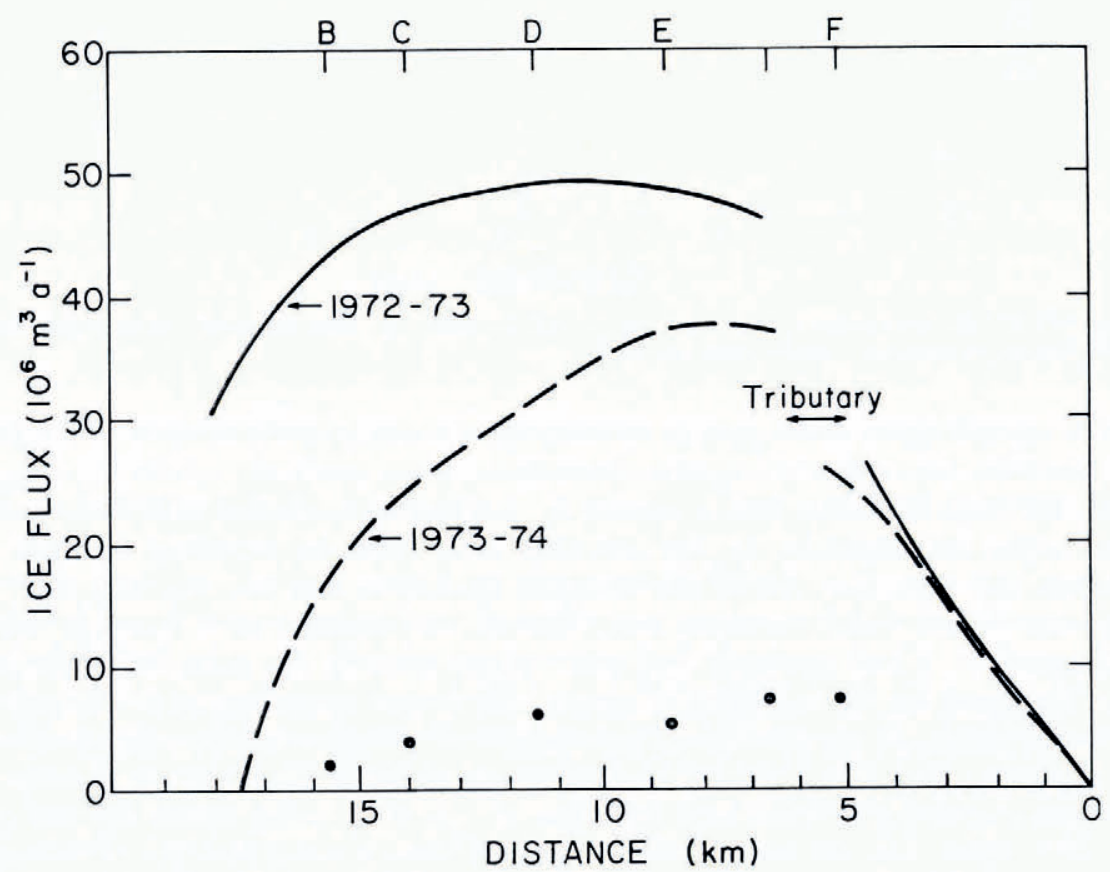

Fig. Io. Curves give balance flux defined by Equation (4). Points show actual ice flux estimated from surface velocity averaged over lateral profiles (Fig. 5) and cross-section areas (Fig. 3). 
An estimate of the actual flux transported by the glacier can be obtained by multiplying the surface speed averaged across the glacier width by the area of the cross-section (Nye, 1965). The results deduced from the speed measurements made over the summer of r973 (Fig. 5) together with the seismically determined cross-section shapes (Fig. 3) are shown in Figure 10. Since the summer velocity is up to $20 \%$ larger than the average annual velocity, these estimates of annual flux may be slightly overestimated.

Even though there is considerable uncertainty in both the balance flux and actual ice transport, it is clear that during 1973 the glacier was transporting much less volume flux than required to achieve steady state. This is expected in a periodically surging glacier at any time between surges, since large amounts of ice are transported down glacier during the surges. Because of the large difference between actual and balance fluxes, the glacier geometry is changing rapidly. The rate of thickness change is given by

$$
\frac{\partial H}{\partial t}=\frac{\mathrm{I}}{W}\left(\frac{\partial Q_{\mathrm{b}}}{\partial x}-\frac{\partial Q}{\partial x}\right)
$$

where $W$ is the glacier width. A thickening in the upper part and thinning in the lower part are already observable after a one-year period, and this pattern of change is reported in DR 74, DR 75, and Bindschadler and others (1976).

A crude estimate can be made of the change in glacier geometry needed in order to achieve steady state assuming the present flow processes as predicted by Equation ( $\mathrm{I}$ ) were to persist uninterrupted into the future. If one considers the equilibrium line, which lies at the location of maximum balance flux, the balance flux is somewhere in the neighborhood of seven times the actual flux. The flux can be increased either by an increase in thickness, large-scale slope, or some combination of these. From Equation ( $\mathrm{I}$ ) the flux can be written as

$$
Q=\bar{u} S=f^{\star} K \frac{2 A}{n+\mathrm{I}}(\rho g f \sin \alpha)^{n} H^{n+5 / 2}
$$

where $\bar{u}=f^{\star} u_{\mathrm{s}}$ is the velocity averaged over the cross-section, and the area $S=K H^{3 / 2}$ with $\kappa$ constant assuming a parabolic cross-section. The factors $f$ and $f^{\star}$ can be found from calculations of Nye (1965, tables IIIB and IV); they depend slightly on $H$, because a change in $H$ causes a change in width ratio, but this dependence is not significant. If the actual flux were to equal the balance flux by increasing only the thickness, it would have to increase by a factor of 1.35 and this would increase the center-line velocity by a factor of 4.5 . On the other hand, if equality were to be achieved by a slope change alone, slope would have to increase by a factor of about I.6 and the velocity would increase by a factor of 7.2. Based on Equation (6) and the current trend of surface-elevation change (Bindschadler and others, I976), the change in surface slope will be most important in the vicinity of the equilibrium line. Elsewhere, this is not necessarily true; for example, in the vicinity of section $\mathrm{F}$ an increasing thickness makes a substantial contribution to a current trend of velocity increase. In any case, to achieve steady state by normal flow processes would require substantially increased shear stress near the base of the glacier over much of its length. On Variegated Glacier and other surge-type glaciers, the course of thickening and steepening which would eventually lead to a steady-state geometry and flow by normal processes is interrupted by the catastrophic instability which leads to the surge.

\section{Acknowledgements}

This work could not have been accomplished without the efforts of many co-workers, too numerous to mention individually, who participated in the field work or supplied logistical support often under extremely difficult conditions. The United States Forest Service and the Bureau of Land Management gave permission for work on the glacier. The work was supported primarily by the National Science Foundation under Grants GA-36039 and GA-36040 
to the Universities of Alaska and Washington, but other institutions, particularly the United States Geological Survey and the California Institute of Technology, participated with independent support.

\section{MS. received 25 May 1976 and in revised form 28 September 1976}

\section{REFERENCES}

Bindschadler, R., and others. 1976. Thermal regime of a surge-type glacier, by R. Bindschadler, W. D. Harrison, C. F. Raymond and C. Gantet. Fournal of Glaciology, Vol. 16, No. 74, p. 251-59.

Bindschadler, R., and others. Unpublished. Variegated Glacier studies, 1973, by R. Bindschadler, W. [D.] Harrison and C. [F.] Raymond. [Available from World Data Center: Glaciology.]

Bindschadler, R., and others. Unpublished. Variegated Glacier studies, 1974, by R. Bindschadler, W. [D.] Harrison and C. [F.] Raymond. [Available from World Data Center: Glaciology.]

Bindschadler, R., and others. Unpublished. Variegated Glacier studies, 1975, by R. Bindschadler, W. [D.] Harrison and C. [F.] Raymond. [Available from World Data Center: Glaciology.]

Budd, W. F. 1968. The longitudinal velocity profile of large ice masses. Union de Géodésie et Géophysique Internationale. Association Internationale d'Hydrologie Scientifique. Assemblée générale de Berne, 25 sept. 7 oct. 1967. [Commission des Neiges et Glaces.] Rapports et discussions, p. 58-77.

Budd, W. F. 1975. A first simple model for periodically self-surging glaciers. Journal of Glaciology, Vol. 14, No. 70, p. 3-2I.

Budd, W. F., and Allison, I. F. [1975.] An empirical scheme for estimating the dynamics of unmeasured glaciers. [Union Géodésique et Géophysique Internationale. Association Internationale des Sciences Hydrologiques. Commission des Neiges et Glaces.] Symposium. Neiges et Glaces. Actes du colloque de Moscow, août rg7ı, p. 246-56. (IAHS-AISH Publication No. 104.)

Budd, W. F., and Jenssen, D. [1975.] Numerical modelling of glacier systems. [Union Géodésique et Géophysique Internationale. Association Internationale des Sciences Hydrologiques. Commission des Neiges et Glaces.] Symposium. Neiges et Glaces. Actes du colloque de Moscow, août r97I, p. 257-91. (IAHS-AISH Publication No. 104.)

Clarke, G. K. C., and Goodman, R. H. 1975. Radio echo soundings and ice-temperature measurements in a surge-type glacier. Fournal of Glaciology, Vol. 14, No. 70, p. 71-78.

Classen, D. F., and Clarke, G. K. C. 197I. Basal hot spot on a surge-type glacier. Nature, Vol. 229, No. 5285, p. $481-83$.

Collins, S. G. 1972. Survey of the Rusty Glacier area, Yukon Territory, Canada, 1967-70. Journal of Glaciology, Vol. I1, No. 62, p. 235-53.

Dobrin, M. 1960. Introduction to geophysical prospecting. [Second edition.] New York, McGraw-Hill Book Co.

Dolgushin, L. D., and Osipova, G. B. [1975.] Glacier surges and the problem of their forecasting. [Union Géodésique et Géophysique Internationale. Association Internationale des Sciences Hydrologiques. Commission des Neiges et Glaces.] Symposium. Neiges et Glaces. Actes du colloque de Moscow, août 1971, p. 292-304. (IAHS-AISH Publication No. 104.)

Glen, J. W. 1955. The creep of polycrystalline ice. Proceedings of the Royal Society of London, Ser. A, Vol. 288, No. 1175 , p. $519-38$.

Goodman, R. H., and others. 1975. Radio soundings on Trapridge Glacier, Yukon Territory, Canada, by R. H. Goodman, G. K. C. Clarke, G. T. Jarvis, S. G. Collins and R. Metcalfe. Journal of Glaciology, Vol. 14, No. 7o, p. $79-84$.

Hallet, B. 1976. Implications of spectral analysis of glacier beds on the sliding of glaciers. Eos. Transactions, American Geophysical Union, Vol. 57, No. 4, p. 325. [Abstract.]

Jarvis, G. T., and Clarke, G. K. C. 1974. Thermal effects of crevassing on Steele Glacier, Yukon Territory, Canada. Journal of Glaciology, Vol. 13 , No. 68, p. 243-54.

Jarvis, G. T., and Clarke, G. K. C. r 975 . The thermal regime of Trapridge Glacier and its relevance to glacier surging. Journal of Glaciology, Vol. I4, No. 7I, p. 235-50.

Kamb, W. B. 1970. Sliding motion of glaciers: theory and observation. Reviews of Geophysics and Space Physics, Vol. 8, No. 4, p. 673-728.

Meier, M. F., and Post, A. S. 1969. What are glacier surges? Canadian Journal of Earth Sciences, Vol. 6, No. 4, Pt. 2, p. $807-17$.

Meier, M. F., and others. 1974. Flow of Blue Glacier, Olympic Mountains, Washington, U.S.A., by M. F. Meier, W. B. Kamb, C. R. Allen and R. P. Sharp. Fournal of Glaciology, Vol. 13, No. 68, p. 187-2 I2.

Nye, J. F. 1952. The mechanics of glacier flow. Fournal of Glaciology, Vol. 2, No. 12, p. 82-93.

Nye, J. F. 1965. The flow of a glacier in a channel of rectangular, elliptic or parabolic cross-section. Fournal of Glaciology, Vol. 5, No. 4I, p. 66r-9o.

Paterson, W. S. B., and Savage, J. C. 1963 . Geometry and movement of the Athabasca Glacier. Fournal of Geophysical Research, Vol. 68, No. I5, p. 45 $3^{1}-20$.

Post, A. S. 1969. Distribution of surging glaciers in western North America. Fournal of Glaciology, Vol. 8, No. 53, p. 229-40.

Robin, G. de Q., and Weertman, J. 1973. Cyclic surging of glaciers. Journal of Glaciology, Vol. 12, No. 64, p. 3-18.

Stanley, A. D. 1969 . Observations of the surge of Steele Glacier, Yukon Territory, Canada. Canadian Journal of Earth Sciences, Vol. 6, No. 4, Pt. 2, p. 819-30.

Tarr, R. S., and Martin, L. 1914. Alaskan glacier studies. Washington, D.C., National Geographic Society. 